\title{
PELATIHAN PEMBUATAN HAND SANITIZER DARI EKSTRAK DAUN SALAM (Syzygium polyanthum) SEBAGAI ALTERNATIF PEMBERSIH TANGAN BEBAS ALKOHOL
}

\author{
Oleh: \\ Nirmala Sari ${ }^{1^{*}}$, Fajriani ${ }^{1}$, Ida Ratna Nila ${ }^{1}$ \\ ${ }^{1}$ Program Studi Fisika Fakultas Teknik Univeristas Samudra \\ 1nirmala_sari@unsam.ac.id
}

\begin{abstract}
Abstrak
Hand sanitizer yang dijual di pasaran umumnya mengandung alkohol yang dapat menyebabkan dehidrasi pada kulit. Oleh karena itu, diperlukan penggunaan bahan-bahan alami yang tidak mengiritasi kulit sebaga alternatif pengganti alkohol, salah satunya adalah daun salam (Syzygium polyanthum). Tanaman salam merupakan salah satu tanaman yang mempunyai kandungan antibakteri. Kandungan utama yang berkhasiat sebagai antibakteri adalah, tannin, flavonoid, minyak atsiri, alkaloid, dan steroid, sehingga hand sanitizer dapat dibuat dengan menggunakan daun salam untuk mengurangi penggunaan alkohol. Pembuatan hand sanitizer daun salam dilakukan dengan beberapa tahap:1) pendidikan masyarakat, 2) Pelatihan pembuatan Hand Sanitizer, 3) Evaluasi. Berdasarkan hasil kegiatan pembuatan hand sanitizer ini dapat disimpulkan bahwa kegiatan ini telah meningkatkan pemahaman pembuatan hand sanitizer dari ekstrak daun salam, sehingga masyarakat bisa mengaplikasikannya dalam kehidupan sehari-hari dengan tujuan untuk menjaga kebersihan tangan agar terhindar dari berbagai penyakit.
\end{abstract}

Kata Kunci: Hand Sanitizer, Daun Salam (Syzygium polyanthum), pelatihan

\begin{abstract}
Hand sanitizers that are sold in the market generally contain alcohol which can dehydrate the skin. Therefore, it is necessary to use natural ingredients that do not irritate the skin as alternatives to alcohol, one of which is bay leaf (Syzygium polyanthum). Salam plant is a plant that has antibacterial properties. The main ingredients that have antibacterial properties are tannins, flavonoids, essential oils, alkaloids, and steroids, so hand sanitizers can be made using bay leaves to reduce alcohol use. The making of the hand sanitizer for bay leaves is carried out in several stages: 1) community education, 2) Training for Hand Sanitizer, 3) Evaluation. Based on the results of the activity of making hand sanitizers, it can be ignored that this activity has increased the understanding of making hand sanitizers from bay leaf extract, so that people can apply it in everyday life with the aim of maintaining hand hygiene to avoid various diseases.
\end{abstract}

Keywords: Hand Sanitizer, Bay leaf (Syzygium polyanthum), workshop

\section{PENDAHULUAN}

Kesehatan merupakan hal dasar yang paling dibutuhkan setiap orang, karena kesehatan sangat berhubungan dengan aspek kehidupan. Salah satu cara menjaga kesehatan tubuh yang sangat sederhana ialah dengan mencuci tangan. Tangan merupakan anggota tubuh yang sangat sensitif terhadap penularan berbagai penyakit termasuk salah satunya Covid 19, yang mana penyakit tersebut saat ini telah ditetapkan oleh WHO (World Health Organization) sebagai pandemi global. Covid 19 dapat menempel pada tangan ketika seseorang melakukan aktivitas. Salah satu cara paling mudah dalam menghambat penyebaran virus, yaitu dengan mencuci tangan menggunakan sabun dan air bersih yang mengalir. Namun, jika seseorang sedang berpergian dan air bersih tidak tersedia, maka perlu alternatif lain untuk menyelesaikan persoalan tersebut, yaitu dengan menggunakan cairan pembersih tangan berbasis alkohol atau mengandung antibakteri yang dikenal dengan hand sanitizer yang penggunaanya sangat praktis dan fleksibel.

Hand sanitizer merupakan inovasi pembersih tangan tanpa air mengalir. Hand sanitizer sudah mulai marak di pasaran yang berbahan dasar alkohol. Namun, penggunaan produk alkohol tertentu sebagai bahan dasar hand sanitizer dalam jangka panjang dapat menyebabkan tangan kering dan menyebabkan dehidrasi pada kulit. Oleh karena itu, diperlukan bahan alternatif yang ramah di kulit dan tidak mengiritasi kulit seperti penggunaan bahan-bahan alami.

Salah satu bahan alami yang mempunyai kandungan antibakteri adalah tanaman salam (Syzygium polyanthum)(Aini, 2018). Tanaman salam mengandung tannin flavonoid, minyak atsiri, triterpenoid, alkaloid, dan steroid. Tanaman salam merupakan tanaman herbal yang berkhasiat sebagai antidiare, antibakteri, antihipertensi, antikolesterol, antioksidan, dan antidiabetik. Tanaman salam yang paling tinggi kandungan 
kimianya ada pada bagian daun. Daun salam rasanya kelat dan bersifat astringent (Salam, 2017). Sehingga tanaman salam ini dapat digunakan sebagai pengganti alkhol dalam penggunaan hand sanitizer.

Ketersediaan produk hand sanitizer di pasaran menjadi barang langka di tengah ancaman pandemi Covid-19. Kelangkaan tersebut disebabkan tingginya tingkat permintaan dari masyarakat. Dengan demikian untuk mengatasi dampak kelangkaan hand sanitizer, maka salah satu caranya adalah dengan membuat hand sanitizer alami dari tanaman daun salam sebagai pengganti alkohol.

\section{METODE}

Seluruh tahapan kegiatan Pengabdian Kepada Masyarakat (PKM) ini dilaksanakan di Desa Sriwijaya Kecamatan Kota Kualasimpang Kabupaten Aceh Tamiang.

Metode yang digunakan untuk menyelesaikan masalah atau persoalan yang dihadapi masyarakat dalam program PKM ini adalah sebagai berikut.

a. Kegiatan pertama dilakukan dengan metode pendidikan masyarakat, yaitu dengan penyuluhan untuk rajin menjaga kebersihan terutama kebersihan tangan sebagai antisipasi dalam menghindari penyebaran virus.

b. Kegiatan kedua dilakukan metode pelatihan dengan melibatkan masyarakat dalam pembuatan hand sanitizer dari ekstrak daun salam.

c. Kegiatan selanjutnya, yaitu monitoring dan evaluasi. Monitoring pada kegiatan ini bertujuan untuk mengetahui bagaimana pelaksanaan pembuatan hand sanitizer dari ekstrak daun salam. Evaluasi hasil kegiatan bertujuan untuk menemukan permasalahan yang terjadi pada saat proses pembuatan hand sanitizer

\section{HASIL DAN PEMBAHASAN}

Kegiatan PKM telah dilaksanakan pada tanggal 19 Agustus 2020 yang diikuti oleh mahasiswa dan 20 peserta dari masyarakat desa Sriwijaya. Kegiatan ini diawali dengan sosialisasi yang dilakukan dengan diskusi bersama masyarakat dengan memberikan informasi terkait pemanfaatan daun salam untuk pembuatan hand sanitizer, dilanjutkan dengan kegiatan pelatihan pembuatan hand sanitizer. Proses pembuatan hand sanitizer dari ekstrak daun salam diawali dengan mempersiapkan alat dan bahan, selanjutnya daun salam dicuci hingga bersih, kemudian dikeringkan selama 3 hari. Setelah dikeringkan daun salam dihaluskan menggunakan blender hingga menjadi serbuk yang kasar.

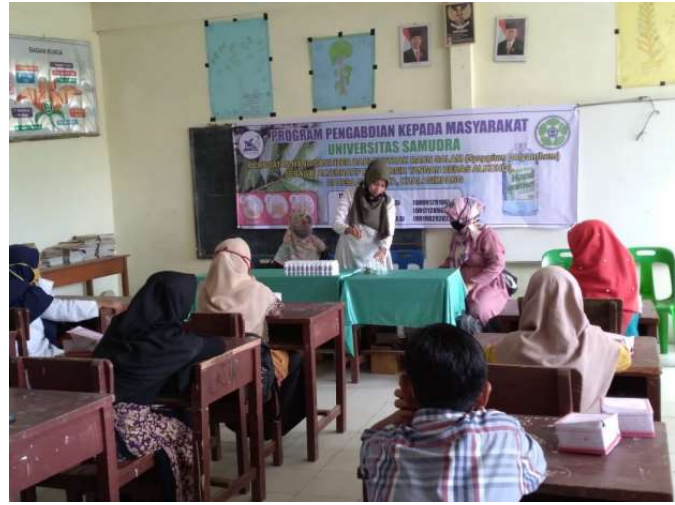

Gambar 1. Pelatihan Pembuatan Hand sanitizer

Tahapan selanjutnya, yaitu mengestrak daun salam, serbuk daun salam ditimbang sebanyak 100 gram dan dimasukkan ke dalam gelas kimia, selanjutnya ditambahkan $800 \mathrm{ml}$ pelarut ethanol $96 \%$. Selama 24 jam serbuk daun salam direndam dengan ditutup menggunakan plastik hitam dan disimpan di tempat yang gelap agar terhindar langsung dari sinar matahari. Selanjutnya rendaman daun salam disaring, hasil penyaringan dipanaskan dengan suhu $80{ }^{\circ} \mathrm{C}$ dengan menggunakan hot plate sampai mengering dan tidak mengandung pelarut lagi.

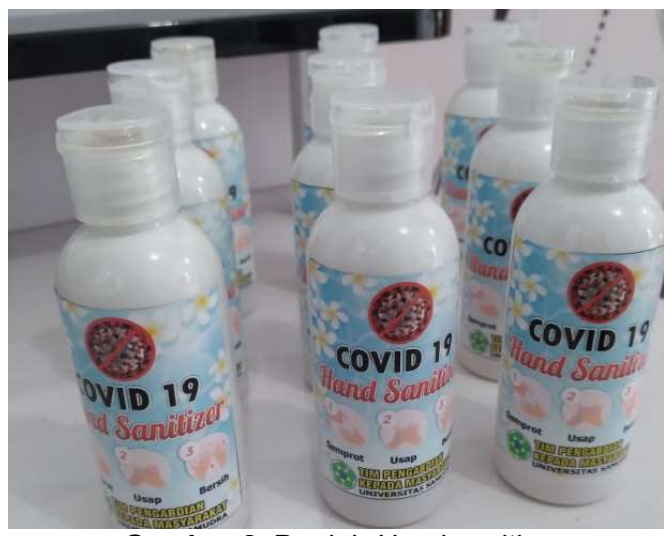

Gambar 2. Produk Hand sanitizer

Pembuatan gel hand sanitizer dilakukan dengan menyiapkan Carbopol 940 sebanyak 1 gram dilarutkan dengan aquades $20 \mathrm{~mL}$ dan diaduk sampai terbentuk masa gel, selanjutnya ditambahkan TEA sebanyak 1 gram. Kemudian metil paraben ditimbang sebanyak 0,2 gram dilarutkan dengan aquades $5 \mathrm{~mL}$, gliserin sebanyak 5 gram ditambahkan, dan diaduk sampai homogen. Ekstrak daun salam ditimbang sebanyak 4 gram dan dilarutkan ke dalam aquades sebanyak $20 \mathrm{~mL}$ dan diaduk sampai larut, aroma lemon ditambahkan sebanyak 3 tetes. Semua bahanbahan tersebut diaduk sampai homogen. 


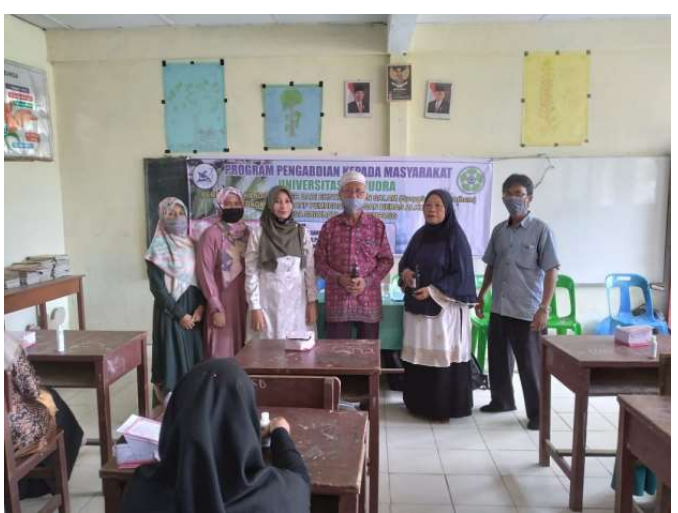

Gambar 3. Penyerahan hand sanitizer kepada masyarakat secara simbolis melalui Datok Penghulu

Peserta pelatihan yaitu masyarakat Desa Sriwijaya diberikan buku saku tentang bagaimana langkah-langkah pembuatan hand sanitizer dari ekstrak daun salam. Setelah pelatihan pembuatan hand sanitizer selesai, peserta diberikan pertanyaan untuk mengetahui tingkat pemahaman masyarakat tentang pembuatan hand sanitizer.

Berdasarkan hasil wawancara dari peserta bahwa peserta sangat antusias dengan pelaihan pembuatan hand sanitizer dengan memanfaatkan daun salam, selama ini masyarakat hanya mengetahui daun salam tersebut digunakan sebagai bumbu masakan namun ternyata daun salam juga dapat digunakan sebagai bahan pembuatan hand sanitizer yang aman serta tidak mengandung alkohol.

\section{SIMPULAN DAN SARAN}

Kesimpulan yang didapat dari kegiatan pengabdian kepada masyarakat ini bahwa masyarakat di Desa Sriwijaya telah berhasil meningkatkan pengetahuan dan keterampilan masyarakat dalam pembuatan hand sanitizer dari ekstrak daun salam sebagai bahan alternatif pengganti alkohol, Peningkatan kemampuan dalam menghasilkan poduk hand sanitizer dari ekstrak daun salam yang dapat menggantikan alkohol dan bernilai jual tinggi akan meningkatkan kemampuan wirausaha masyarakat.

\section{DAFTAR PUSTAKA}

Adrianto, M. F., \& Rudyanto, M. (2020). Pelatihan pembuatan produk susu probiotik-sari buah bagi. 6(1), 13-17.

Aini, N., Meiliawati, A., Pramanti, N., Amalia, L. Z., Fairuz, G. A., Puspito, R. I., \& Retnoningrum, D. (2018). Hand sanitizer ekstrak daun trembesi (albizia saman (jacq.) Merr) aroma anggur sebagai antiseptik. Jurnal Kedokteran Diponegoro, 7(1), 359-365.

IImiah, K. T., \& Simatupang, E. J. (2018). Formulasi Sediaan Gel Hand Sanitizer Dari Ekstrak Etanol Daun Jambu Air (Syzygium aqueum (Burm. F.) Alston).

Salam, D., Polyanthum, S., \& Walp, W. (2017). Pembuatan Dan Karakterisasi Ekstrak Kering Daun Salam. Jurnal Farmasi Higea, 7(1) 54-62.

Widyawati, L., Mustariani, B. A. A., \& Purmafitriah, E. (2017). Formulasi Sediaan Gel Hand Sanitizer Ekstrak Etanol Daun Sirsak (Annona Muricata Linn) Sebagai Antibakteri Terhadap Staphylococcus Aureus. Jurnal Farmasetis, 6(2), 47-57. 